\title{
Sustainability of global and international business operations during the adversity and hardship
}

\author{
Ramo Palalic $^{1^{*}}$, Robert D. Hisrich ${ }^{2}$, Leo Paul Dana ${ }^{3}$, Veland Ramadani ${ }^{4}$ \\ ${ }^{1}$ Management Department, Sultan Qaboos University, Oman \\ ${ }^{2}$ Department of Marketing and Entrepreneurship, Kent State University, USA \\ ${ }^{3}$ Rowe School of Business, Dalhousie University, Canada \\ ${ }^{4}$ Faculty of Business and Economics, South East European University, North Macedonia
}

\begin{abstract}
*...orresponding author: r.palalic@ @su.edu.om, ramopal@gmail.com
Received Aug. 19, 2021

Revised Nov. 14, 2021

Accepted Nov. 24, 2021

\section{Abstract}

The COVID-19 pandemic has altered the way business is conducted. The widespread closure of commercial organizations presents opportunities to reset the way business activities are conducted. Regardless of the organization's size or its status as a domestic or international firm, due diligence is required to find solutions that will allow firms to sustain their business activities in uncertain times. This study addresses this issue and attempts to identify issues that require urgent attention so that organizations can be effective and efficient in their global operations. In this context, the study proposes three imperatives for global/international businesses to sustain their operations in the long term. These imperatives include having a strong reserve fund, access to a local mutual fund, and networking to form alliances in host countries. Other implications are discussed, and we identify areas for future research.
\end{abstract}

(C) The Author(s) 2022

Published by ARDA.
Keywords: MNEs, Networking, Alliances, Local mutual funds, Reserve funds, Sustainability, Pandemic, COVID-19

\section{Introduction}

Since the early $19^{\text {th }}$ century, business organizations have been seeking ways to expand their operations internationally. These efforts were intensified since the end of the Second World War, as barriers to international trade and investment have gradually reduced. However, the pandemic in 2020 disrupted and slowed down these activities to the extent that some multinational enterprises (MNEs) and firms involved in international business (such as export firms and international suppliers and buyers) ceased their global operations permanently, resulting in a large number of job losses. Just in the United States of America (USA), 97,966 businesses were permanently shut (Fortune, 2021) ${ }^{1}$. MNEs in the USA account for $22 \%$ of people employed; in the Netherlands, they account for $20 \%$, while in China, they are responsible for $6.4 \%$ of urban employment (World Bank 0WB, $2020)^{2}$. The pandemic showed that even global businesses could be hurt too, with the revenue of the top 5,000 global companies falling by roughly $30 \%$ in the year 2020. In certain MNEs, revenues fell by as much as $200 \%$, which can cause long-term harm to global supply chains since the greater part of FDI comprises reinvested income by these companies. New greenfield projects are being deferred for unspecified periods, and transnational mergers and acquisitions have decelerated drastically in contrast to previous years, dropping down

\footnotetext{
${ }^{1}$ https://fortune.com/2020/09/28/covid-buisnesses-shut-down-closed/ Accessed on February 27, 2021

2 https://blogs.worldbank.org/psd/foreign-direct-investment-and-global-value-chains-wake-covid-19 Accessed on February 27,2021

This work is licensed under a Creative Commons Attribution License (https://creativecommons.org/licenses/by/4.0/) that allows others to share and adapt the material for any purpose (even commercially), in any medium with an acknowledgement of the work's authorship and initial publication in this journal.
} 
by $50-70 \%$ internationally in April 2020 (WB, 2020) ${ }^{3}$ Prior to the pandemic, international firms were able to sustain their business activities by relocating their operations and exploiting opportunities in a business-friendly environment, and in return, they contributed to the socio-economic development of that country. Hence, MNEs", have at least a two-fold impact on a global scale. One is to maximize profits over a long period of time. The other is to act as a socially responsible corporate citizen in the host economy and employ local people. This two-fold strategy is captured in the "GloCal" (think globally and act locally) mindset [1]. Going global is motivated by the MNEs' desire to maximize profits, while acting locally requires adapting/customizing products or services to the local environment and be socially responsible in providing jobs to locals.

The COVID-19 force majeure has made operating business truly uncertain and challenging to follow the GloCal strategy. However, it does not mean that all businesses around the globe have lost their values. Some international firms are in the envious position of succeeding during the pandemic and reporting high profits. This study provides an overview of the challenges that were faced by international firms in the pre-pandemic era and how they were managed. What we can learn from those challenges can help us address some of the issues faced by firms during the pandemic, which threaten the very existence of these organizations.

\section{Theoretical framework}

\subsection{Golden old days for international business: sweet challenges}

As the global world became a small village, businesses at the global scale were growing rapidly. However, obstacles remained in managing certain issues that could impact the international firms in the countries where they operate. These obstacles threaten the sustainability of the businesses in the long run. We highlight five of the key challenges in this paper.

\section{Sustainability's challenge 1: Cultural environment and international business}

What was a challenge for international business around the world? One of the gurus in cross-cultural management was [2] who built the basis for the management of business across different cultures or nations around the globe. In his work, he has highlighted the importance of cultural dimensions that each culture in the world has. Thus, being unaware of the cultural settings alludes to consequences that might be towards possible business failure. In this regard, many authors [3-6] have clarified the importance of the cultural settings from different regions and perspectives highlighted by [2] and those who followed him [7].

For many years it has been an issue of adaptation of global business to a culture that the business wants to enter [8] where cultural animosity was one of the main issues. Either to adapt or standardize [5], managers had to choose to enter such markets. In this regard, [5] argued this adaptation strategy regarding the culture by two types, "adaptation by indifference" and "adaptation by submission". The first one is having a manager that will run the business locally by which an international company is assimilated into the local culture without negative consequences. The other one is to adapt to the local culture as the international manager adapts to all cultural attributes $[9,10]$ to have a successful business.

Operating in the international market is truly complex and challenging. MNEs are surrounded by different political, social, economic, and other factors, which also require very complex strategic decisions [4, 11, 12]. However, all such challenges have been over, and small or big businesses were aware of them, and there learned how to make the bridge between cultural differences to run the business successfully.

\section{Sustainability's challenge 2: Managing human resources in international business}

Another aspect that was and still is important is managing human resources in international and multinational businesses. It is so for small businesses, as highlighted by [13] as strategic human resource management (SHRM). Managing employees with different backgrounds, ethnic, national, regional, religious, gender-wise, was always peace of daily activities of managers and leaders in companies, supported by the HR department to

\footnotetext{
${ }^{3}$ https://blogs.worldbank.org/psd/foreign-direct-investment-and-global-value-chains-wake-covid-19 Accessed on February 27, 2021
} 
develop companies' flesh human capital and maintain it in the long-term. Managing a workforce overseas was known as cross-cultural management [14], which can be defined as managing a business outside of home's country by accepting differences in culture, and other values and beliefs to maintain and grow the business. Hence, this process of accepting differences was supported by HRM practices by providing different professional seminars and developments [13] to managers and employees and to make sure that two different countries' cultural practices will not be questionable.

Such an important role of HRM in MNCs was argued by [15], whose standpoint is that MNCs at the strategic level should have a balance between local and international human capital. Being such diverse, it gives wind in the back of the company regarding creativity and innovation [16] because a great pool of different views and ideas can conceive awesome ideas and solutions. That is why MNCs are known for being vigorous in terms of highly talented management and employee force, as well as for outstanding HRM practices [17]. Being such agile companies, they try to adapt quickly as a local firm does [18]. Such adaptation goes in line with the $20^{\text {th }}$ century's term known as "glocal": think globally, act locally.

\section{Sustainability's challenge 3: Marketing activities in international business}

When globalization appeared on horizons, national borders were not that important. There was a free and fast movement of goods, services, and capital, from the East to the West. That was what we could see on the surface of international business. However, the real challenges are how to sell products and services for the global market? Well, in the $21^{\text {st }}$ century, a very known proverb illuminated: "think globally, act globally". This required international or global brands to use the local power to be accepted in the market [1]. In other words, it is necessary to fully adapt to the consumers' preferences [19] in the region an international brand does business with.

Although many books and chapters that we came across suggested adaptation as the main key to entering the global market. One of the reasons for the adaptation is to overcome "ethnocentrism", which is like a moral obligation to support domestic products [20], and thus it is very difficult to take the peace of the cake in the market. Sometimes it is good to have a balanced approach regarding full customization/adaptation and full standardization [21], which of course, does not apply to every part of the world. Thus, going international or global is a true challenge that may lead to a very quick failure [22]. However, all constraints are being observed and given directions [1, 19-23] on how an international/global brand should behave to succeed in the global arena. In every business attempt, international businesses will use either adapt or standardize [24].

\section{Sustainability's challenge 4: Political uncertainty and advancement in the new technology}

Many times were challenged with strong lobbying when entering the global market. Sometimes it requires some issues to be resolved at the political level, especially when there are disputes between particular countries, which in reality provides or suggests a different mode of entries [25] in that particular market [26]. Yet, a challenge is when taking over is to happen internationally, the political affinity of local CEO makes an obstacle for further takeover [27].

Further obstacles for an international business are if we are talking state-owned firms, which political or similar ideology must be followed [28]. It denotes that state-owned firms may have even more difficulties to be successful in international/global markets [29] as there exists animosity between the two countries. Similarly, it is challenging if the market has an obstacle in terms of "informal institutions" [30], which international/global brands must overcome too. These facts allude that uncertainty, like political one, plays an important constraint in the sustainability of international/global business. Simply, the host environment is powerful [31], and usually of the global business should be adopted, and in some circumstances, if possible, adopted.

Sustainability's challenge 5: Anti-globalization campaign and corporate and social responsibility (CSR) According to Deutsche Welle (DW) ${ }^{4}$, anti-globalization unofficially started in 1999. Then, it has spread out around the globe from the West to the East. From the USA over Europe to the Middle East, Africa, Asia,

${ }^{4}$ https://www.dw.com/en/a-brief-history-of-the-anti-globalization-movement/g-39573255 Accessed on 27 th February 2021 
Australia. The movement has been raised due to different perspectives on globalization. For some, it is inevitable for socio-economic development, and for others, it is an unjust system with negative consequences. Antiglobalists argue that globalization brings the only outcome, which was discussed by different researchers with respect to the labor force [32, 33], environment and pollution, especially in China [34], human rights [35-37], and injustice [38] in general. In the same line, it has been recorded that "sweatshops" were created, which has wiped out all labor and even human rights. However, not all international or multinational companies are doing such injustice to the world, as anti-globalists see. In this context, many employees were happy to work for an international or multinational company, having in mind its just and standardized HR policies that they can be effective and successful. But not all multinational brands do take care of such details, but rather, the first and foremost is to earn as much as possible. These habits of international/multinational companies happen in undeveloped or developing countries where labor is poorly paid, and the environmental degradation (pollution) has increased. Meanwhile, investment in developed or industrialized countries they adapted and yet contributes to the social and corporate responsibility (CSR) as argued by different research $[39,40]$.

Arguments exist on both sides, however, MNCs and IBs have successfully applied CSR and other responsibilities, especially it can be seen if a country has strongly set such requirements for the FDI.

As argued above, there are challenges that were required to overcome and to gain long-term sustainability, which is depicted in Figure 1 below.

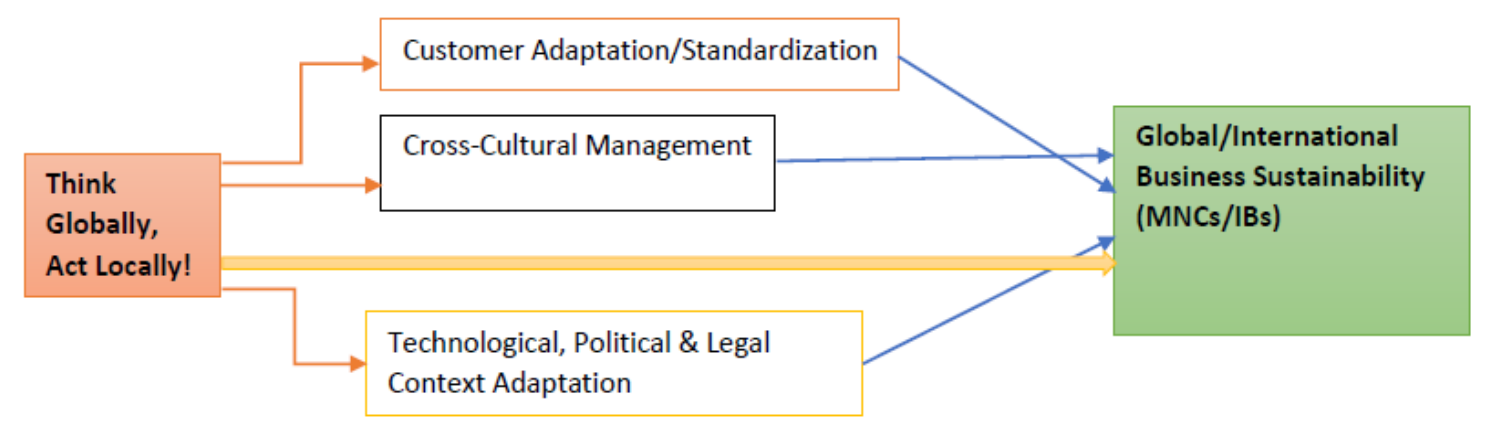

Figure 1. Sustainability Model before the pandemic. Source: Authors' compilation

The figure suggests that if a business goes globally/internationally, besides other factors, it has to observe the adaptation/standardization of products and services according to consumers' wants and demands [1, 19-23]. Besides that, the business should pay attention to managing people locally and expatriates so that they are synchronized and synergetic, which is known as cross-cultural management [41-43], which is very critical to manage it efficiently and effectively. And finally, political, legal [44] and technological circumstances play an important innovation role [45] in business success and sustainability.

\section{Discussion and conclusion}

\subsection{Discussion}

This section will point out some of the arguments that can extend the theory of the MNCs sustainability as well as the practicality when hard times are on the horizon. It is important for MNC/IB to assimilate to the local environment and, in some cases, to give up on eventual corporate rigidity and culture. Hence, the following three imperatives suggest an approach of managing MNCs/IBs and implementing a more organic approach due to the necessity of sustainability of the businesses in host countries.

\section{Abandoning old comfort zone: A new challenge for international business and its sustainability}

A long time ago, Socrates wrote: "The secret of change is to focus all of your energy, not on fighting the old, but on building the new." This quote could be observed and discussed from different perspectives. One of them could be that a new era of pandemic came, and it should be treated as something that so far has no clear solution when it comes to global businesses. Thus, new paths of sustainability have to be found. 
Zahra [46] posed interesting two questions in regard to the current pandemic: "How will the world look postCovid-19? What is the role of international entrepreneurship (IE) in this new world?" Suggested answers lied in the scope and types of the global business that is yet to come. As for the long-term sustainability in global business, many different factors shall be taken to have global or international business successful. Besides the constraints or challenges explained in Figure 1, nowadays, in the pandemic, it has been shown that digitalization plays an important role in its sustainability. As argued by [47], there was a dramatic shift in the digitalization of the business. The business of the digital platforms has never been better, and they are doubled and even more, like Zoom, Microsoft Teams, Google Meet [47], etc. As this is the case, we can say, and we witness that advancement in the new technology and digitalization is still an active role in businesses' sustainability. This is a voice of future changes in the global competition, which will change its nature [48]. Besides this, global businesses are also still facing challenges, as in Figure 1. However, new approaches should be introduced to enhance the sustainability of modern multinational/international business across the globe.

In order to implement the old-new "Think globally, act locally" [1], the study proposes the crucial points that are important to sustain in pandemic for the long term. These are imperatives for MNCs/IBs to establish: 1) own reserve funds, 2) local mutual funds, and 3) local networking. In this case, global businesses will be led by: $B e$ global, Be local (GloBeLo). To implement this slogan in hard times, we propose the following imperatives for MNCS/IBs, big or small.

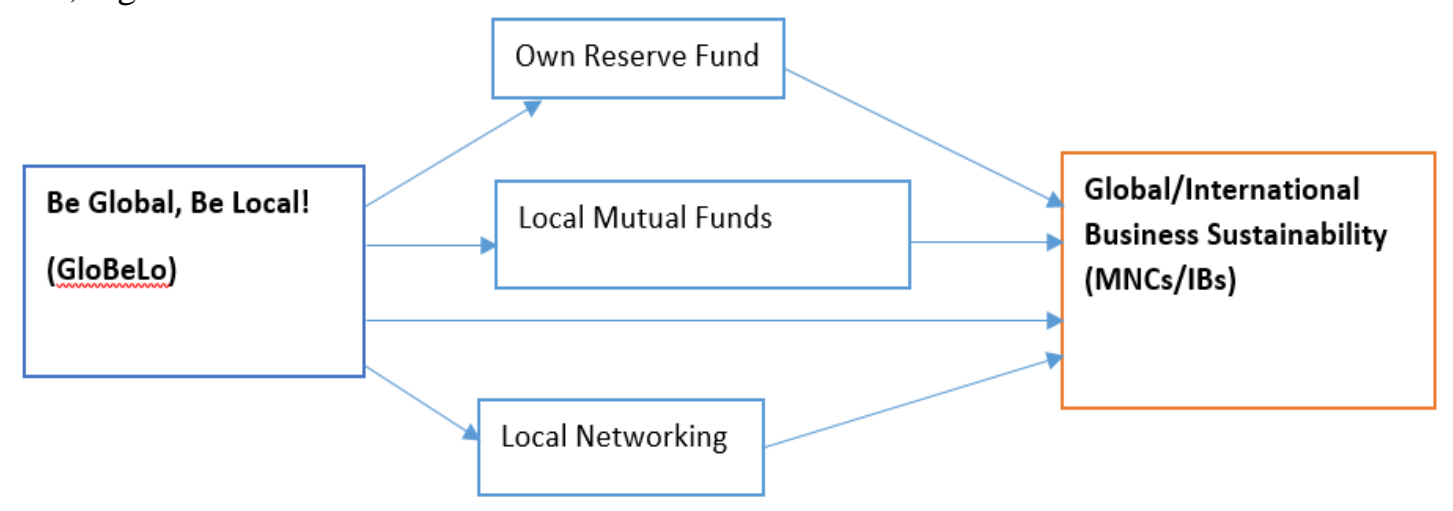

Figure 2. Path Model for International/Global Business Sustainability in Hardship (Pandemic). Source: Authors' compilation

\section{Imperative 1: Setting own reserve fund $(s)(R F)$}

Covid-19 showed that many businesses who were on edge were no stronger to continue their business activities. Some of them stayed tuned and got loans from commercial banks. Borrowing money at the moment of uncertainty was not an option, but it was the only. If businesses fail, depending on the capital invested and riskshare, that might be worse, hurting even private properties. However, some companies tried to survive, and there were waiting for a few months of governmental support. The support was not that quick (especially in developing countries/countries in transition), so that could save all jobs and continuance of the business. This situation showed that it is necessary to revive self-sustainability by setting the funds out of its revenues.

This reserve fund would be set up gradually, allocating some amounts of money from the revenue to achieve at least its minimum. This minimum amount that should be available is one year running a business without interruption if a hard time comes so that the business will over the situation or transform itself into something else and continue its existence in another form. To overcome the situation or transform the business into something else needs time and money. Do in both cases, it should be imperative for small or big businesses to have this reserve fund. What is the amount of one year running the business? This will further depend on the size of the company and the size of the business. So, each business has its diagnosis and knows how much money it needs to be run for a one-year minimum.

MNCs and IBS, instead of closing down their branches, can act as a local business setting up the minimum reserve fund for one year of running the business and their operations. 
Imperative 2: Local mutual funds ( $L M F)$

Another option to have sustainability while global crisis for MNCs/IBS is to establish or join local mutual funds in a country it has its operations. In this case, MNE or IB branch in a particular country should have a strategy to join local fund cooperation if it exists. This fund can help without taking advantage to survive for a short period of time. And either to continue the current business or to restructure/reform/into a new mode of business. Such mutual funds at the local level can lead to establishing a great network that will provide many benefits to the local funds members to overcome certain situations which can negatively affect business operations in global markets.

\section{Imperative 3: Local networking (LN)}

The advantage of local networking was discussed by [49] [50]as well as by [51] in the context of Small and medium enterprises (SMEs) that should have a collaboration that will help them to grow [52] and be sustainable [53]. Similarly, MNCs/IBs can behave as local SMEs and establish collaboration and networking in the local market. This will bring a variety of benefits, like supply-chain, IT solutions, and other partnership possibilities that can increase the strength [54] of local MNC or local IB. Such networking can be a good approach to even governmental negotiations (alliances) for a more favorable business environment for all [55]. Even local MNCs can make alliances based on their structure [56] and give a great network made of few of them that can function well [56]. While taking this option, such alliances will differ which will depend on the cultural profile [57] of hosted country and its values, and also on its internal structure [58] of MNC/IB, which the same origin of $\mathrm{MNC/IB}$ may differ across the branches [58] in the host country.

\section{Conclusion}

Caryn Sullivan quotes: "In the face of adversity, we have a choice. We can be bitter, or we can be better...". So, are MNCs/IBs have a choice? Competition in the global business has changed and alludes that we will witness more changes in the future [48]. It may force the current MNEs to be stretched out to have an effect $[56,59]$ in their global operations. Such urge forces all businesses to restructure and transform from one mode of nosiness to another, trying and accepting the best options. In this context, the study has proposed the approach that will make MNCs/IBs more sustainable in host countries during hardship Figure 2. The following were proposed.

- Forming alliances across the host country is inevitable for MNCs/IBs, whose success may be subject to different constraints $[57,58]$. Forming such alliances, using the networking approach $[52,55]$ in the local settings. Being an active member or a partner of the local SMEs will benefit the MNC/IB to sustain [49-51] and grow [52].

- Ideally, such networking with benefits will open the possibility of establishing the local mutual funds that will help all players in the host country to survive or to transform its business into a new opportunity.

- The third point is to have its own reserve fund that the business will count on it when there is a need for that, as the time of the pandemic, that is still not over.

\section{Theoretical and practical implications}

Having in mind the above propositions, the study contributes to the literature in extending the theoretical approach in MNCs/IBs' sustainability. The contribution is in MNCs/IBs' theory as well as theory applied in the global arena [22]. Given the pandemic, theories and earlier findings should be discussed more and eventually reconsidered as new recipes for global business are imperative. From the practical viewpoint, the pandemic caused to review the implementation of global business operations that requires a new approach of organizational strategy and structure to accomplish organizational goals.

Due to time constraints, the study has limitations reflected in the future works that can be done to support this initial work. Thus, this research opens the following questions that can be for a global business perspective:

1. Does pandemic or similar hard time theory and practice could be applied worldwide? And, do the following still work during the hardship: 

a. Adaptation/standardization?
b. Managing HRM across nations?
c. Political and legal constraints?

2. What then will be the organizational structure of MNC/IB's branches in host countries?

\section{Declaration of competing interest}

The authors declare that they have no any known financial or non-financial competing interests in any material discussed in this paper.

\section{References}

[1] H. Huang and J. He, "When face meets globalization," International Marketing Review, vol. 38, no. 1, pp. 184-203, 2019.

[2] G. Hofstede, Culture's consequences: International differences in work-related values. Sage. London, 1980.

[3] B. Rosenbloom and T. Larsen, "Communication in international business-to-business marketing channels," Industrial Marketing Management, vol. 32, no. 4, pp. 309-315, 2003.

[4] A. Barron, "Exploring national culture's consequences on international business lobbying," Journal of World Business, vol. 46, no. 3, pp. 320-327, 2011.

[5] A. Apetrei, N. I. Kureshi, and I. A. Horodnic, "When culture shapes international business," Journal of Business Research, vol. 68, no. 7, pp. 1519-1521, 2015.

[6] P. Khakhar and H. G. Rammal, "Culture and business networks: International business negotiations with Arab managers," International Business Review, vol. 22, no. 3, pp. 578-590, 2013.

[7] R. House, Javidan, Mansour, Hanges, Paul, Dorfman, Peter "Understanding cultures and implicit leadership theories across the globe: an introduction to project GLOBE," Journal Of World Business, vol. 37, pp. 3-10, 2002.

[8] J. N. Sheth, "Clash of cultures or fusion of cultures?: Implications for international business," Journal of International Management, vol. 12, no. 2, pp. 218-221, 2006.

[9] R. Palalic, El Mustapha, A.S.M, "Transformational leadership and MNCs: evidence from Morocco community," Journal of Enterprising Communities: People and Places in the Global Economy, vol. 14, no. 2, pp. 201-230, 2020.

[10] R. Palalic, V. Ramadani, and L. P. Dana, "Entrepreneurship in Bosnia and Herzegovina: focus on gender," European Business Review, vol. 29, no. 4, pp. 476-496, 2017.

[11] S. Srivastava, S. Singh, and S. Dhir, "Culture and International business research: A review and research agenda," International Business Review, vol. 29, no. 4, p. 101709, 2020.

[12] G. Magnani, A. Zucchella, and D. E. Floriani, "The logic behind foreign market selection: Objective distance dimensions vs. strategic objectives and psychic distance," International Business Review, vol. 27, no. 1, pp. 1-20, 2018.

[13] V. Ramadani, Memili, E., Palalić, R., Chang, E.P.C.,, Entrepreneurial Family Businesses: Innovation, Governance, and Succession. Springer, 2020, p. 210.

[14] A. Bird and M. E. Mendenhall, "From cross-cultural management to global leadership: Evolution and adaptation," Journal of World Business, vol. 51, no. 1, pp. 115-126, 2016.

[15] C. Gomez and J. I. Sanchez, "HR's strategic role within MNCs: helping build social capital in Latin America," The International Journal of Human Resource Management, vol. 16, no. 12, pp. 2189-2200, 2005.

[16] U. Andersson, À. Dasí, R. Mudambi, and T. Pedersen, "Technology, innovation and knowledge: The importance of ideas and international connectivity," Journal of World Business, vol. 51, no. 1, pp. 153$162,2016$.

[17] G. Wood, F. L. Cooke, M. Demirbag, and C. Kwong, "International Journal of Human Resource Management (IJHRM) Special Issue on: International human resource management in contexts of high uncertainties," The International Journal of Human Resource Management, vol. 29, no. 7, pp. 1365$1373,2018$.

[18] M. Brookes, C. Brewster, and G. Wood, "Are MNCs norm entrepreneurs or followers? The changing relationship between host country institutions and MNC HRM practices," The International Journal of Human Resource Management, vol. 28, no. 12, pp. 1690-1711, 2017. 
[19] M. Fregidou-Malama, E. H. Chowdhury, and A. S. Hyder, "Innovative product marketing strategy: multinational companies in Bangladesh," Journal of Asia Business Studies, vol. 13, no. 4, pp. 656-671, 2019.

[20] T. Thomas, N. Singh, and K. G. Ambady, "Effect of Ethnocentrism and Attitude Towards Foreign Brands in Purchase Decision," Vision: The Journal of Business Perspective, vol. 24, no. 3, pp. 320329, 2019.

[21] J. Širaliova and J. J. Angelis, "Marketing strategy in the Baltics: standardise or adapt?," Baltic Journal of Management, vol. 1, no. 2, pp. 169-187, 2006.

[22] B. I. Park and J. Y. Lee, "The survival of the fittest in the global markets: multinational corporation challenge, evolution and decline," Management Decision, vol. 59, no. 1, pp. 1-17, 2021.

[23] A. W. Hao, J. Paul, S. Trott, C. Guo, and H.-H. Wu, "Two decades of research on nation branding: a review and future research agenda," International Marketing Review, vol. 38, no. 1, pp. 46-69, 2019.

[24] D. Vrontis, A. Thrassou, and I. Lamprianou, "International marketing adaptation versus standardisation of multinational companies," International Marketing Review, vol. 26, no. 4/5, pp. 477-500, 2009.

[25] A. Delios and P. W. Beamish, "Survival and Profitability: The Roles of Experience and Intangible Assets in Foreign Subsidiary Performance," The Academy of Management Journal, vol. 44, no. 5, pp. 1028-1038, 2001.

[26] D. Rottig, S. Muscarella, and R. Torres de Oliveira, "Managing formal institutional challenges when entering Cuba: A multinational corporation perspective," International Journal of Emerging Markets, vol. 15, no. 1, pp. 24-49, 2019.

[27] J. Li and C. Qian, "Principal-principal conflicts under weak institutions: A study of corporate takeovers in China," Strategic Management Journal, vol. 34, no. 4, pp. 498-508, 2013.

[28] R. Aguilera, P. Duran, P. P. M. A. R. Heugens, S. Sauerwald, R. Turturea, and M. VanEssen, "State ownership, political ideology, and firm performance around the world," Journal of World Business, vol. 56, no. 1, p. 101113, 2021.

[29] A. Cuervo-Cazurra and C. Li, "State ownership and internationalization: The advantage and disadvantage of stateness," Journal of World Business, vol. 56, no. 1, p. 101112, 2021.

[30] J. J. Boddewyn and M. W. Peng, "Reciprocity and informal institutions in international market entry," Journal of World Business, vol. 56, no. 1, p. 101145, 2021.

[31] J. Henisz Witold and A. Delios, "Learning about the institutional environment," in The New Institutionalism in Strategic Management, vol. 19, I. Paul and S. S. Brian, Eds. (Advances in Strategic Management: Emerald Group Publishing Limited, 2000, pp. 339-372.

[32] S. Parsa, I. Roper, M. Muller-Camen, and E. Szigetvari, "Have labour practices and human rights disclosures enhanced corporate accountability? The case of the GRI framework," Accounting Forum, vol. 42, no. 1, pp. 47-64, 2019.

[33] T. Sendlhofer and C. M. Lernborg, "Labour rights training 2.0: The digitalisation of knowledge for workers in global supply chains," Journal of Cleaner Production, vol. 179, pp. 616-630, 2018.

[34] J. Zhang, J. Wang, X. Yang, S. Ren, Q. Ran, and Y. Hao, "Does local government competition aggravate haze pollution? A new perspective of factor market distortion," Socio-Economic Planning Sciences, p. 100959, 2020.

[35] L. J. Obara and K. Peattie, "Bridging the great divide? Making sense of the human rights-CSR relationship in UK multinational companies," Journal of World Business, vol. 53, no. 6, pp. 781-793, 2018.

[36] P. Sikka, "Accounting for human rights: The challenge of globalization and foreign investment agreements," Critical Perspectives on Accounting, vol. 22, no. 8, pp. 811-827, 2011.

[37] S. Ullah, K. Adams, D. Adams, and R. Attah-Boakye, "Multinational corporations and human right violations in emerging economies: Do commitment to social and environmental responsibility matter?," J Environ Manage, vol. 280, p. 111689, Feb 152021.

[38] M. A. Islam, C. Deegan, and S. Haque, "Corporate human rights performance and moral power: A study of retail MNCs' supply chains in Bangladesh," Critical Perspectives on Accounting, vol. 74, p. 102163, 2021.

[39] A. Kolk, "The social responsibility of international business: From ethics and the environment to CSR and sustainable development," Journal of World Business, vol. 51, no. 1, pp. 23-34, 2016.

[40] D. Jamali, T. Jain, G. Samara, and E. Zoghbi, "How institutions affect CSR practices in the Middle East and North Africa: A critical review," Journal of World Business, vol. 55, no. 5, p. 101127, 2020. 
[41] J. F. L. Hong, R. S. Snell, and M. Easterby-Smith, "Cross-cultural influences on organizational learning in MNCS: The case of Japanese companies in China," Journal of International Management, vol. 12, no. 4, pp. 408-429, 2006.

[42] E. Hartmann, E. Feisel, and H. Schober, "Talent management of western MNCs in China: Balancing global integration and local responsiveness," Journal of World Business, vol. 45, no. 2, pp. 169-178, 2010.

[43] M. Owusu Ansah, L. Louw, and J. Belso-Martinez, "The influence of national culture on organizational culture of multinational companies," Cogent Social Sciences, vol. 5, no. 1, p. 1623648, 2019.

[44] D. M. Rotting, Sebastian; de Oliveira,Rui Tores, "Managing formal institutional challenges when entering Cuba A multinational corporation perspective," International Journal of Emerging Markets, vol. 15, no. 11, pp. 24-49, 2019.

[45] J. Cantwell, "Innovation and international business," Industry and Innovation, vol. 24, no. 1, pp. 4160, 2016.

[46] S. A. Zahra, "International entrepreneurship in the post Covid world," Journal of World Business, vol. 56, no. 1, p. 101143, 2021.

[47] P. M. Leonardi, "COVID-19 and the New Technologies of Organizing: Digital Exhaust, Digital Footprints, and Artificial Intelligence in the Wake of Remote Work," Journal of Management Studies, vol. 58, no. 1, pp. 249-253, 2020.

[48] A. Delios, G. Perchthold, and A. Capri, "Cohesion, COVID-19 and contemporary challenges to globalization," Journal of World Business, vol. 56, no. 3, p. 101197, 2021.

[49] H. Etemad, Wright, R.W., Dana, L.P., "Symbiotic International Business Networks: Collaboration between Small and Large Firms," Thunderbird International Business Review, vol. 43, no. 4, pp. 481499, 2001.

[50] R. W. Wright and L.-P. Dana, "Changing Paradigms of International Entrepreneurship Strategy," Journal of International Entrepreneurship, vol. 1, no. 1, pp. 135-152, 2003/03/01 2003.

[51] L. P. Dana, H. Etemad, and R. W. Wright, "The Global Reach of Symbiotic Networks," Journal of Euromarketing, vol. 9, no. 2, pp. 1-16, 2001/01/05 2001.

[52] I. Martins, "Network Usage, Entrepreneurial Orientation and Their Effectiveness on SMEs Growth," The Journal of Entrepreneurship, vol. 25, no. 1, pp. 18-41, 2016.

[53] J. Abbas, S. Raza, M. Nurunnabi, M. S. Minai, and S. Bano, "The Impact of Entrepreneurial Business Networks on Firms' Performance Through a Mediating Role of Dynamic Capabilities," Sustainability, vol. 11, no. 11, p. 3006, 2019.

[54] S. Tallman and A. S. Chacar, "Communities, alliances, networks and knowledge in multinational firms: A micro-analytic framework," Journal of International Management, vol. 17, no. 3, pp. 201$210,2011$.

[55] J. Kim, "Networks, Network Governance, and Networked Networks," International Review of Public Administration, vol. 11, no. 1, pp. 19-34, 2006.

[56] S. J. Cranmer, B. A. Desmarais, and J. H. Kirkland, "Toward a Network Theory of Alliance Formation," International Interactions, vol. 38, no. 3, pp. 295-324, 2012.

[57] S. Varma, R. Awasthy, K. Narain, and R. Nayyar, "Cultural determinants of alliance management capability - an analysis of Japanese MNCs in India," Asia Pacific Business Review, vol. 21, no. 3, pp. 424-448, 2015.

[58] B. Bos, D. Faems, and F. Noseleit, "Alliance Concentration in Multinational Companies: Examining Alliance Portfolios, Firm Structure, and Firm Performance," Strategic Management Journal, vol. 38, no. 11, pp. 2298-2309, 2017.

[59] A. P. J. Schotter, M. Stallkamp, and B. C. Pinkham, "MNE Headquarters Disaggregation: The Formation Antecedents of Regional Management Centers," Journal of Management Studies, vol. 54, no. 8, pp. 1144-1169, 2017. 